\title{
微粉粒子の新・表面改質, 球形化法に関する研究*
}

\author{
中 村 裕 計*1, 社河内 敏 彦*2
}

\author{
A New Surface Fusing, Globular Forming Method of Fine Particle
}

\author{
Hirokazu NAKAMURA and Toshihiko SHAKOUCHI*3
}

${ }^{* 3}$ Graduate School of Engineering, Mie University, 1515 Kamihama-cho, Tsu-shi, Mie, 514-8507 Japan

\begin{abstract}
In this study, a new surface fusing, globular forming method of fine particle by high temperature air jet flow is proposed in order to improve the performance of the former one. First, the flow and heat transfer of a high temperature air jet flow are made clear experimentally. Secondly, the behavior of particle of a few micron meter order in a high temperature air jet flow is examined by numerical analysis and flow visualization. Finally, the performance of a new surface fusing or globular forming system is investigated, and a large improvement and the most suitable shape of the nozzle system are shown.
\end{abstract}

Key Words: Gas-Solid Jet Flow, Globular Forming, High Temperature Air Jet Flow, Flow and Heat Transfer

\section{1. 緒 論}

高温空気噴流は, 乾燥や粉体の表面改質, 球形化処 理などで広く使用されているが, 中でも粉体処理にお いて高温空気噴流から微粉粒子への伝熱特性は十分に 解明されていない.

一般に, 数 $\mu \mathrm{m}$ の大きさの粉体を工業的に大量に製 造する方法の一つに, 固気二相噴流を衝突板に衝突さ せて粗大粒子を粉砕するジェット粉砕法(1) がある. 粉砕された微粉粒子の形状は凹凸のある不定形状であ るが,これら粉体材料の機能を改善・向上させるため に粒子形状を均一化, 球形化(2)する要求がある. 例え ば, 複写機のカラートナーでは粒子の球形化により, 帯電性の均一化, および耐久性や流動性が向上し, そ の結果, トナーの転写効率や画質の向上などが可能と なる. 近年, これらの要求を満たすトナーの製造方法 として, 重合法 ${ }^{(3)} に$ 代表される化学反応による方法が あるが, 使用する有機溶媒の処理や生産コストが高い などの問題がある.こうした問題に対して, 製造プロ

* 原稿受付 2004 年 3 月 19 日.

*1 三重大学大学院工学研究科( $514-8507$ 津市上浜町 1515).

*2 正員, 三重大学大学院工学研究科.

E-mail : shako@mach.mie-u.ac.jp
セスの簡略化, 操作性の簡便性の観点から, 乾式で連 続的な処理を行う方法として, ジェット粉砕法で製造 された微粉粒子を高温空気噴流中に流入させて溶融 し, 粒子の表面張力によって球形化させる方法が注目 されている.しかし, 高温空気噴流の生成には大きな 熱量が必要であり, そのうえ, 微粉粒子の処理速度が 小さいなどのため, 装置のエネルギー効率の改善・向 上が望まれている.

本研究では, まず, 高温空気噴流から微粉粒子への 伝熱量と表面改質特性の関係を明らかにし, 次いで, 高温空気噴流中に流入された数 $\mu \mathrm{m} \sim$ 数十 $\mu \mathrm{m}$ の微粉 粒子の飛行軌跡を, 数值解析および流れの可視化・観 察結果から明らかにした。

さらに, 円形ノズル形表面改質, 球形化装置 ${ }^{(4)}$ (図 1 , 以後, 円形ノズル形とも呼ぶ)の主ノズルから噴出さ れる高温空気噴流 $\left(300^{\circ} \mathrm{C}\right)$ と高温空気噴流出口近傍の 円周上 4 箇所に設けられた副ノズルからの噴流 $\left(20^{\circ} \mathrm{C}\right)$ が衝突後, 混合・拡散するようすを温度分布の測定か ら明らかにし,これらの知見をもとに球形化装置の性 能を改善・向上させることを目的として,す心゙ての粒 子が均一な高温領域を通過する高温空気噴流の流れ 場, 温度場を作り出すために, 三重管ノズル形表面改 質, 球形化装置 (図 2 , 以後, 三重管ノズル形とも呼ぶ) 
を新たに提案した。

円形ノズル形では, 供試微粉粒子が主噴流の周りか ら流入されるのに対し，新たに提案した三重管ノズル 形では, 温度の高い主噴流の中心部に直接流入され る. 円形ノズル形と三重管ノズル形で表面改質, 球形 化を行った場合のエネルギー効率を比較し，供試微粉 粒子(トナー, 軟化点: $\left.120^{\circ} \mathrm{C}\right)$ の同一の球形化に対し て三重管ノズル形のエネルギー効率が, 円形ノズル形 の約 5.3 倍にもなり非常に優れた球形化特性を有する ことなどを示す。

\section{2. おもな記 号}

$$
\begin{aligned}
& C_{D}: \text { 抵抗係数 } \\
& C_{p}: \text { 圧力係数 }=2\left(p-p_{a}\right) /\left(\rho u_{m}^{2}\right) \\
& C_{p}: \text { 定圧比熱 } \mathrm{kJ} /(\mathrm{kg} \cdot \mathrm{K}) \\
& d: \text { 直径 } \mathrm{mm} \\
& F: \text { 流量 } \mathrm{Nm}{ }^{3} / \mathrm{min} \\
& G: \text { 供給速度 } \mathrm{kg} / \mathrm{h} \\
& k: \text { 熱伝導率 } \mathrm{W} /(\mathrm{m} \cdot \mathrm{K}) \\
& L_{m}: \text { 管端の長さ } \mathrm{mm} \\
& m: \text { 質量 } \mathrm{kg} \\
& N u: \text { ヌッセルト数 } \\
& p: \text { 圧力 } \mathrm{kg} / \mathrm{cm}^{2} \\
& \operatorname{Pr}: \text { プラントル数 } \\
& Q_{1}: \text { 単位時間あたりの伝熱量 } \mathrm{W} \\
& Q_{2}: \text { 全体の伝熱量 } \mathrm{J} \\
& Q_{3}: \text { 高温空気噴流の熱量 } \mathrm{kJ} / \mathrm{h} \\
& r: \text { 半径方向座標 } \mathrm{mm} \\
& R e: \text { レイノルズ数 } \\
& R_{p}: \text { 平均円形度 } \\
& T: \text { 温度 }{ }^{\circ} \mathrm{C} \\
& t: \text { 滞留時間 } \mathrm{s} \\
& u: \text { 平均流速 } \mathrm{m} / \mathrm{s} \\
& x: \text { 流れ方向座標 } \mathrm{mm} \\
& \eta: \text { エネルギー効率 } \mathrm{kg} / \mathrm{kJ} \\
& \nu: \text { 動粘性係数 } \mathrm{m}{ }^{2} / \mathrm{s} \\
& \rho: \text { 密度 } \mathrm{kg} / \mathrm{m}^{3} \\
& \sigma: \text { エネルギー効率比 } \\
& \psi: \text { 流れ関数 } \\
&
\end{aligned}
$$

(下付き添字)

$$
\begin{aligned}
a & : \text { 空気相 } \\
c & : \text { 中心線 } \\
m & : \text { 主ノズル } \\
\max & : \text { 最大値 } \\
m u & : \text { 三重管ノズル形 } \\
p & : \text { 粒子相 }
\end{aligned}
$$

$$
\begin{aligned}
s & : \text { 副ノズル } \\
\mathrm{se} & : \text { 二次空気 } \\
r & : \text { 円形ノズル形 }
\end{aligned}
$$

\section{3. 表面改質, 球形化装置の原理と構造}

図 1,2 にそれぞれ, 円形ノズル形と三重管ノズル形 球形化装置の概略図を示す。いずれも，供試微粉粒子 を高温空気噴流中に流入させて微粉粒子を溶融し球形 化する装置で, 微粉粒子を分散させる分散領域と高温 空気噴流中に微粉粒子を流入させて球形化する表面改 質, 球形化領域, および球形化後に微粉粒子を冷却さ せる冷却領域とから構成されている。なお，これらの 球形化装置の構造は簡単で, 機内に可動部分を有さな い.

図 3 に, 実験装置の全体図を示す。主ノズル(円形

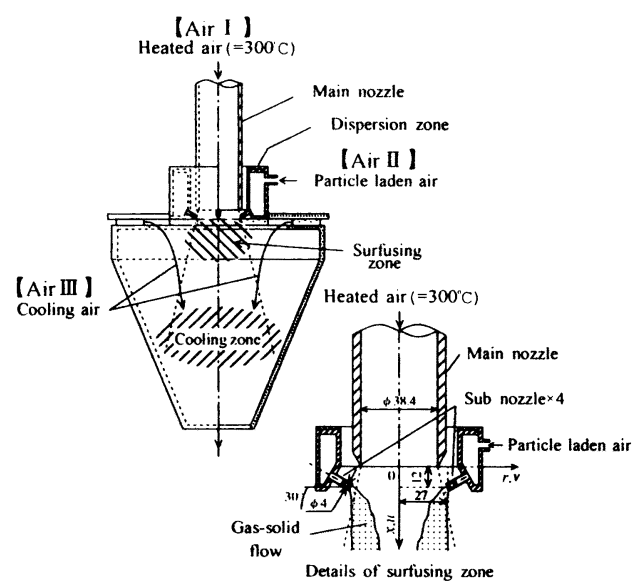

Fig. 1 Surfusing system with pipe nozzle

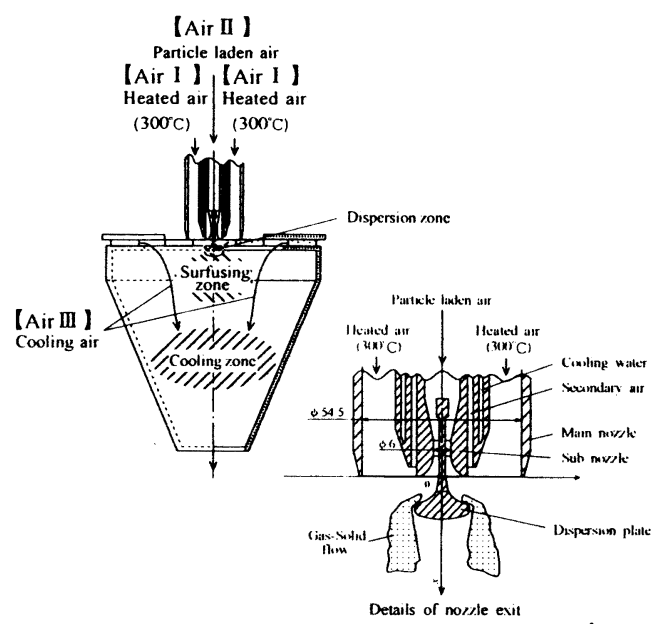

Fig. 2 New surfusing system with three nozzle 
ノズル)からの高温空気噴流, Air I $\left(300^{\circ} \mathrm{C}\right)$ と微粉粒 子を含む固気二相噴流, Air II $\left(20^{\circ} \mathrm{C}\right)$ および冷却空気 流, Air III ( $\left.20^{\circ} \mathrm{C}\right)$ は, 球形化装置(9内を通った後, サ イクロン(12)で微粉粒子と気流に分離され, 気流は集じ ん機(14)を通ってブロワより系外へ排出される.

円形ノズル形では, フィーダ10により定量供給され た粉体原料は, 粉体供給用エゼクタノズル(11), 分散部 を通った後, 高温空気噴流出口直後近傍の円周上 4 箇 所に設けられた副ノズルから, 球形化領域に噴出され る. 副ノズル内で急速に加速され完全分散に近い状態 で噴出された微粉粒子は, 上部に設けられた主ノズル (8)からの高温空気噴流 Air I 中に噴出される.

新たに提案した三重管ノズル形では，すべての粒子 を高温領域を通過させることを意図し，主ノズルの中 心に設置した副ノズルから微粉粒子を噴出する構造と した. また，微粉粒子が高温領域に噴出される直前で 高い分散状態にするため, 副ノズル出口近傍で粒子に せん断力を与えることを意図し, 副ノズル出口部に絞 り部を設けた。 また，微粉粒子のさらなる分散状態の 向上と主噴流(高温空気噴流) と副噴流 (常温空気噴流) の素早い混合を行うことで均一な高温領域をすべての 粒子が通過するように, 副ノズル後方に分散板を設置 した.さらに, 高温空気噴流中に流入する直前で, 微 粉粒子にせん断力を加えることで完全分散状態に近い 状態になるように二次空気を周囲から導入した。この 二次空気は，分散板の冷却効果も意図している.

三重管ノズル形の場合, フィーダ(10により定量供給 された粉体原料は, 粉体供給用エゼクタノズル(11)で吸 引され主ノズル内の中心位置に設置した副ノズル内で 急速に加速され, 副ノズル出口の後方の分散板に衝突

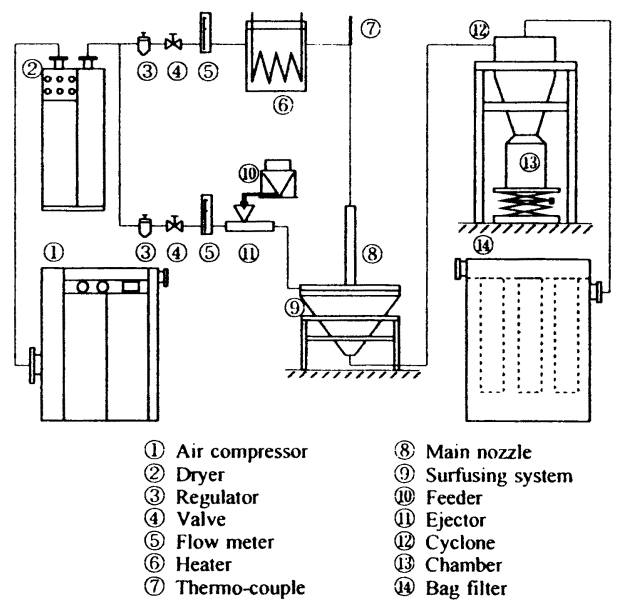

Fig. 3 Experimental set up
し, より完全分散に近い状態となる. その後, 微粉粒 子は, 分散板外周方向に飛跡を変え, また, 周囲より 導入される二次空気によるせん断力を受け, 高い分散 状態で球形化領域に噴出される. 噴出された微粉粒子 は, 最外周の主ノズル8からの高温空気噴流 Air I 中 に噴出される.その後, 円形ノズル形および三重管ノ ズル形の場合, ともに高温空気噴流中に流入した微粉 粒子(トナー)の温度は軟化点 $\left(120^{\circ} \mathrm{C}\right)$ まで上昇し溶融 状態になり, 粒子自身の表面張力により球形化され る. その後, 外部から導入された冷却空気流 Air III により冷却, 固化されサイクロンで捕集される.

\section{4. 数 值 解 析}

主噴流に向かって微粉粒子を含む副噴流が噴出され る流れ場（図 4)の流動状態と微粉粒子の飛行飛跡につ いて, 数值的な解析を試みた.まず, 単相空気流の流 れ場を Navier-Stokes 式, 連続式, $k-\varepsilon$ 乱流モデルに よる乱流輸送方程式を有限差分法で解くことから明ら かにした. 乱流成分は, ランダムシミュレーションで 評価した. 次いで, この流れ場に副ノズルから単一の 球形粒子が空気噴流とともに噴出された場合の飛行軌 跡を, 次の粒子の運動方程式を解くことから求めた.

$$
\begin{aligned}
& m_{p} d \boldsymbol{u}_{p} / d t=C_{D} \pi d_{p}^{2} \rho_{a}\left(\boldsymbol{u}_{a}-\boldsymbol{u}_{p}\right)\left|\boldsymbol{u}_{p}-\boldsymbol{u}_{a}\right| \\
& +m_{p} g\left(1-\rho_{a} / \rho_{p}\right)
\end{aligned}
$$

なお, 粒子の抵抗係数 $C_{D}$ は次式で与えた.

$$
C_{D}=24 / \operatorname{Re}_{p}
$$

粒子が気相に与える影響, および粒子同士の衝突は考 慮していないが, 本研究では粒子の質量比が小さいの で問題ないと考えられる。

図 4 に, 球形化部のフローモデルと座標系, および 記号の一部を示す. 流れは軸対称なので, $r$ の正の領

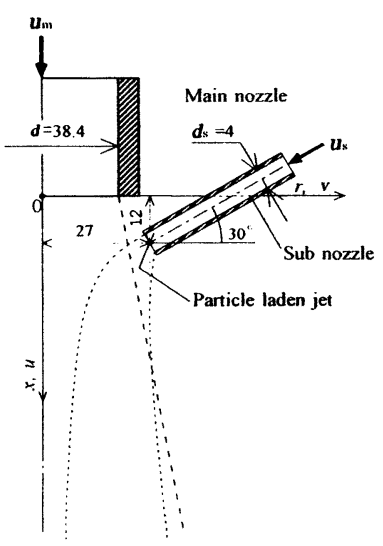

Fig. 4 Flow model 
域のみが示されている. 空気噴流は, 直径 $d=38.4$ $\mathrm{mm}$ の主ノズルから平均流速 $u_{m}=33 \mathrm{~m} / \mathrm{s}$ で噴出され る. 副ノズルの直径は $d_{s}=4 \mathrm{~mm}$ で, 主ノズル出口中 心から $(x, r)=(12,27 \mathrm{~mm})$ の位置に $r$ 方向に対して $30^{\circ}$ の角度で円周上の 4 箇所に設置され, 微粉粒子を 含む固気二相噴流が平均流速 $u_{s}=33 \mathrm{~m} / \mathrm{s}$ で噴出され る. 粒子径 $d_{p}=2,5,10 \mu \mathrm{m}$, 真比重 $\rho_{p}=600 \mathrm{~kg} / \mathrm{m}^{3}$ の粒子を副ノズルの中心から噴出させた. 流出位置に おける粒子の初期速度は, 気相の速度と同一とし, 運 動方程式の解法にはルンゲ・クッ夕法(5)を用いた。 計算領域は $x \times r=576 \times 269 \mathrm{~mm}$ の領域を，それぞれ $155 \times 269$ の不等間隔格子で分割し数值解析に供した。

\section{5. 実験装置と実験方法}

$5 \cdot 1$ 微粉粒子への伝熱量と球形化特性 微粉粒 子[ポリエステル系トナー, 平均円形度 (円相当径の 円周長さを粒子の投影像の周囲長さで除したもの)： $R_{p}=0.919$, 平均粒子径 : $d_{p} 50=8.8 \mu \mathrm{m}$, 密度 : $\rho_{p}=$ $600 \mathrm{~kg} / \mathrm{m}^{3}$, 軟化点: $\left.T_{\mathrm{mel}}=120^{\circ} \mathrm{C}\right]$ を溶融, 球形化す るために必要な微粉粒子への伝熱量 (温度場と微粉粒 子の滞留時間)を, 図 5 に示す環状ノズルを用いて検 討する. 内径 $d_{m}=54.5 \mathrm{~mm}$ の主ノズルの出口平均流 速を $u_{m}=21 \mathrm{~m} / \mathrm{s}=$ 一定とし, 噴流温度を, $T=150$, $250,300^{\circ} \mathrm{C}$ (図 3 の熱電対(7)で測定) と変化させて, 微 粉粒子を, 内径 $d_{s}=5.0 \mathrm{~mm}$ の分散副ノズルから平均 流速 $u_{s}=21 \mathrm{~m} / \mathrm{s}$ で高温空気噴流の中心から噴出させ た.また, 微粉粒子の高温領域での滞留時間を制御す るために, 管端の長さ $L_{m}$ を 0 400 $\mathrm{mm}$ に変化させ た.

微粉粒子の球形化性能は, 平均円形度で評価した. 円形度の測定には, 単一粒子の投影像から画像処理で 球形度合を求めるフロー式粒子像分析装置 [シスメッ クス (FPIA-2100) ] を使用した. 微粉粒子 $\left(d_{p}=8.8\right.$ $\mu \mathrm{m})$ へ単位時間あたりの伝熱量 $Q_{1}$ は, 以下の式(6) で求められる.ただし, 粒子速度は気相の速度と同一 とした。

$$
Q_{1}=\pi k d_{p}\left(T-T_{p}\right)\left(2+0.6 \operatorname{Re}_{p}^{0.5} \operatorname{Pr}^{0.33}\right)
$$
ここで,

$$
R e_{p}=\left(u_{m}-u_{p}\right) d_{p} / \nu
$$

したがって, 時間 $t$ の間の伝熱量 $Q_{2}$ は

$$
Q_{2}=Q_{1} t
$$

$5 \cdot 2$ 高温空気噴流の温度場の測定 円形および 三重管ノズル形の主ノズルからの高温空気噴流の温度 分布をサーモグラフィー[日本アビオニクス (TVS$2000 \mathrm{MK} 2)$ ]を用いて測定した. ただし, 空気など の気体自体からは赤外線の放射がないため, 高温空気

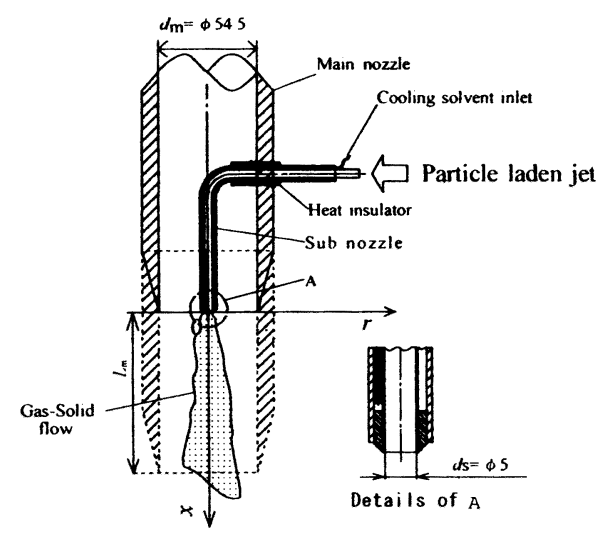

Fig. 5 Shape of annular nozzle

噴流の温度分布を直接測定することはできない．本実 験では, 厚さ $1 \mathrm{~mm}$, 長さ $400 \mathrm{~mm}$, 幅 $100 \mathrm{~mm}$ の天然 ゴム板を, 主ノズル出口中心断面の流れ方向に設置し, 高温空気噴流によって加熱されたゴム板の温度分布が 定常状態になった後に, ゴム板から放射される赤外線 をサーモグラフィーで測定しそれを高温空気噴流の温 度分布として求めた。 また，物質固有の放射率による 影響をなくすため, ノズル出口での熱電対による温度 測定值とサーモグラフィーの温度測定值とが一致する ように放射率の校正を行った。

$5 \cdot 3$ 微粉粒子の球形化特性 微粉粒子の球形化 特性は, 図 1,2 に示す円形ノズル形および三重管ノズ ル形9を使用して検討した。高温空気噴流(主ノズル) の流量は $F_{m}=1.0 \mathrm{Nm}^{3} / \mathrm{min}$, 噴流温度は円形ノズル 形の主ノズル出口での最大温度 $T_{\max }=300^{\circ} \mathrm{C}=$ 一定と した。それに対し，三重管ノズル形の主ノズル出口で 最大温度は $T_{\max }=250,300^{\circ} \mathrm{C}$ と変化させた。微粉粒子 を噴出させる副ノズル出口平均流速は, 両者の場合と もに $u_{s}=33 \mathrm{~m} / \mathrm{s}=$ 一定である.また, 三重管ノズル 形の二次空気流量は, $F_{s e}=0.16 \mathrm{Nm}^{3} / \mathrm{min}$ である.

円形ノズル形では, フィーダ10からの微粉粒子(ポ リエステル系トナー)の供給速度は $G=0.3,1.3,2.7$ $\mathrm{kg} / \mathrm{h}$ で, 三重管ノズル形では, $G=6.0 \mathrm{~kg} / \mathrm{h}=$ 一定で ある. 球形化された微粉粒子は, 平均円形度とカップ リング [粒子同士の造粒度合，＝(改質後の $50 \%$ 粒子 径) -(改質前の 50\%粒子径)] で球形化特性を評価し た. カップリングの測定には, 粒度測定器 [コールタ (Multisizer II)] を使用した。

\section{6. 結 果と考察}

$6 \cdot 1$ 微粉粒子への伝熱量と球形化特性 図 6 に, 各温度における微粉粒子の平均円形度と微粉粒子の高 
温領域通過時間 $t$ との関係を示す。 $t$ は, 主ノズル内 通過時間 $\left(\Delta t_{1}=L_{m} / u_{s}\right)$ とノズル出口以降で微粉粒子 の球形化に寄与する高温領域通過時間 $\Delta t_{2}$ の和であ る.ノズル出口以降の高温領域滞留時間 $\Delta t_{2}$ は, 高温 空気噴流の温度 $T=150^{\circ} \mathrm{C} の$ 実験結果 (図 6 中, -印) を表す線形の最小二乗法を用いて求めた曲線が供試原 料の平均円形度 $R_{p}=0.919$ と交わる点を求めると $L_{m}$ が $0 \mathrm{~mm}$ の位置での高温領域滞留時間は, $\Delta t_{2} \fallingdotseq 1.4 \times$ $10^{-2} \mathrm{~s}$ となる。 なお,この時間は, $T=250,300^{\circ} \mathrm{C}$ 場 合も同様であると仮定した。

$T=150^{\circ} \mathrm{C}$ の場合, 平均円形度は $t$ の増加とともに あまり大きく向上しないが, 温度が高い $T=250$, $300^{\circ} \mathrm{C}$ 場合には, 高温領域通過時間が短いにもかか わらず, 平均円形度が $R_{p} \fallingdotseq 0.97$ まで急速に増大す る.

図 7 は, 平均円形度と式 $(3) \sim(5)$ を用いて求めた 高温空気噴流加ら微粉粒子 $d_{p}=8.8 \mu \mathrm{m}$ への伝熱量と の関係を示す。図7にはまた, 粒子形状がわかる SEM の写真を示した. 平均円形度は, 微粉粒子への 伝熱量が増加するとともに改善・向上される(7).この ことは, SEM の写真から明りょうに見てとれる.

また, 平均円形度と伝熱量との関係は,

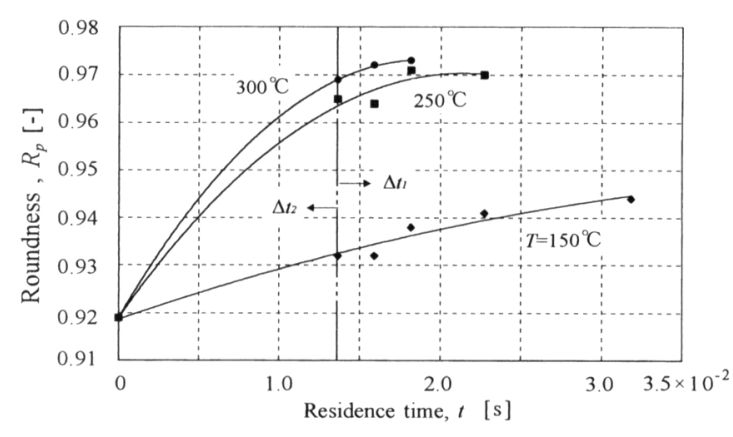

Fig. 6 Roundness and residence time

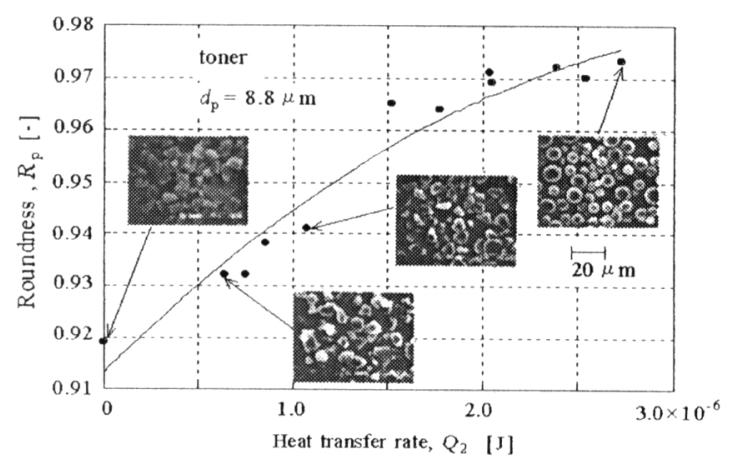

Fig. 7 Roundness and heat transfer rate to fine particle

$$
\begin{aligned}
& R_{p}=\left(-4.84 \times 10^{9}\right) Q_{2}^{2}+36000 Q_{2}+0.91 \cdots(6) \\
& \text { ただし, } R_{p}[-], Q_{2}[\mathrm{~J}] \text { である. }
\end{aligned}
$$

$6 \cdot 2$ 高温空気噴流の温度場 図 8,9 は, 円形， ズル形および三重管ノズル形の高温空気噴流の温度分 布を示す. 主ノズルからの高温空気噴流の流量は $F_{m}$ $=1.0 \mathrm{Nm}^{3} / \mathrm{min}$, 主ノズル出口での噴流温度は最大温 度 $T_{\max }=300^{\circ} \mathrm{C}$, それぞれの副ノズル出口平均流速は $u_{s}=33 \mathrm{~m} / \mathrm{s}$ である.また, 三重管ノズル形の二次空 気流量は, $F_{\mathrm{se}}=0.16 \mathrm{Nm}^{3} / \mathrm{min}$ である.

円形ノズル形の場合, 主ノズルからの高温空気噴流 は副ノズルからの噴流と衝突, 干涉し, 中心方向へ縮 流する. その後, 副噴流と混合し, 中心線上温度 $T_{c}$ は, 下流に向かって急速に減衰する。 また, 供試卜ナ 一微粉粒子の軟化点が $T_{\mathrm{mel}}=120^{\circ} \mathrm{C}$ なの゙, 高温領域 を $T_{c}>120^{\circ} \mathrm{C}$ 領域とすると, それは $x / d<3$ まで存 在する.

三重管ノズル形の場合, 主ノズルからの高温空気噴 流は, 主ノズル中心位置に設置された副ノズルからの 噴流と二次空気噴流が分散板に衝突し, その周囲に沿 って流れるため環状に流下する。また, 常温の副噴流 と二次空気噴流は, $x / d \fallingdotseq 0.5$ で半径方向に最も大き く広がり下流にいくにつれ高温空気噴流と混合するた め, 中心線上温度 $T_{c}$ は上昇し, $x / d \fallingdotseq 3$ で最大 $T_{c}=$ $180^{\circ} \mathrm{C}$ とる. また, $T_{c}>120^{\circ} \mathrm{C}$ 高温領域は, $x / d<4$ の領域まで存在する.

$6 \cdot 3$ 数值解析 図 10 に, 円形および副ノズルの 出口平均流速が $u_{m}, u_{s}=33 \mathrm{~m} / \mathrm{s}$ の場合の流動特性を 流線と等圧線(計算結果)で示す. 図 10 中の数值はそ れぞれ, 流れ関数 $\Psi$, 圧力係数 $C_{p}[=2(p$ $\left.\left.-p_{a}\right) /\left(\rho u_{m}^{2}\right)\right]$ の值である. 円形ノズルからの噴流は 副ノズルからの噴流と衝突, 干渉し,いくぶん中心方 向へ縮流する. また圧力は, 円形ノズルからの噴流と 副ノズルからの噴流との衝突部で大きな值をとり，下 流方向に向かって減少する.

図 11 に, 前記の流れ場中を飛行する粒径 $d_{p}=2,5$, $10 \mu \mathrm{m}$ の微粉粒子の飛行軌跡を示す. 粒子は円形ノズ ルからの噴流流れの影響を強く受け下流方向に軌跡を 曲げ, その後流れに従って飛行する. 粒径の小さな粒 子 $\left(d_{p}=2 \mu \mathrm{m}\right)$ は, その慣性力が小さく気相の運動が支 配的になるためそれに従って軌跡を大きく曲げ, 空気 噴流の中心部に到達せずに噴流の流れに沿って進む. 粒子径が大きくなると $\left(d_{p}=10 \mu \mathrm{m}\right)$, 粒子の慣性力が 大きくなるので直線的に飛行する区間が長くなるが, 主噴流の中心部に到達する前に噴流の流れに従って飛 行する.上記の解析結果から, $d_{p}=10 \mu \mathrm{m}$ までの微粉 粒子は主ノズルより噴出された空気噴流の中心部には 


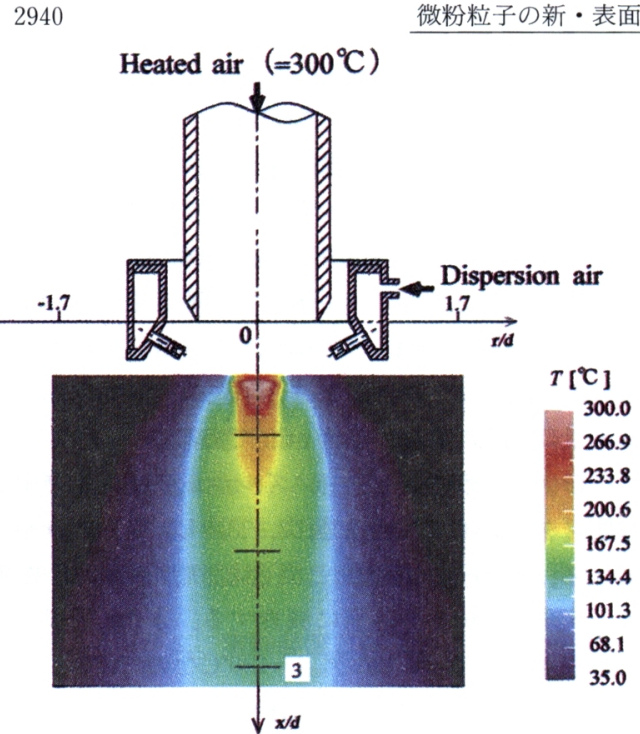

Fig. 8 Temperature profile of the pipe nozzle

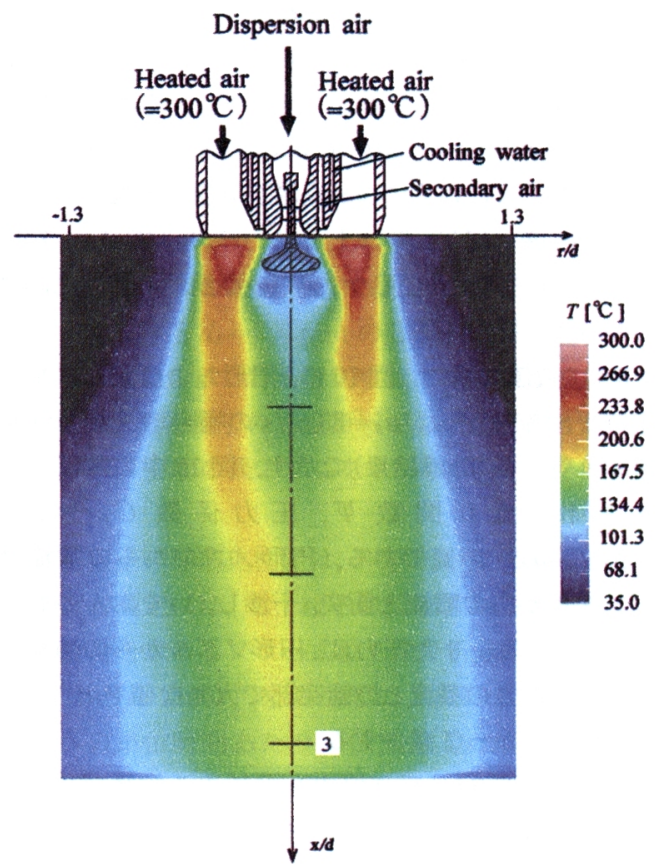

Fig. 9 Temperature profile of the three nozzle

到達せず，噴流の外側を飛行する，供試粒子の $50 \%$ 粒 子径は $d_{p}=8.8 \mu \mathrm{m}$ で, $10 \mu \mathrm{m}$ 以上の粒子の個数は約 $10 \%$ 程度であることから, 粒子の大部分は先に述べた 高温空気噴流の外側 (低温領域) を飛行していると考え られる。

図 12,13 は, 上述の温度場中を飛行する微粉粒子の 飛行軌跡を可視化・記録し，その飛行範囲をスケッチ

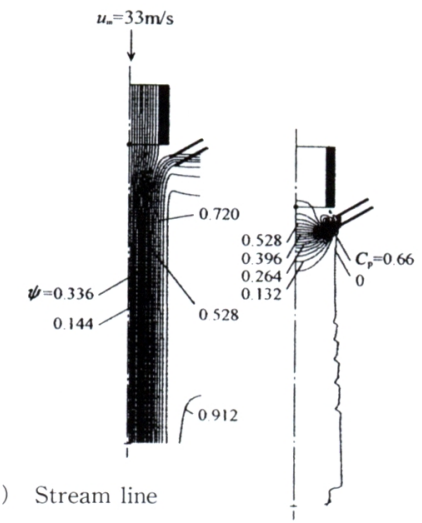

(b) Contour of pressure

Fig. 10 Flow characteristics

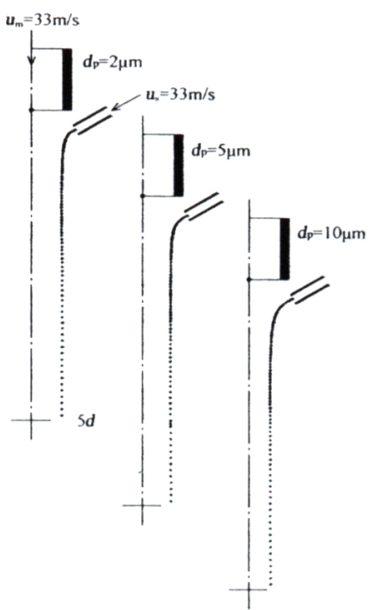

Fig. 11 Particle trajectory (calculation)

で示す．供試粒子は，前述のポリエステル系トナーで ある・

円形ノズル形の場合, 微粉粒子の飛行軌跡は, $x / d$ $\fallingdotseq 1.4$ で高温空気噴流の中心部に到達するものから, 同時に噴流外縁部に沿って飛行するものがあり, 下流 に向かって広がりながら飛行する.

三重管ノズル形の場合, 微粉粒子の飛行軌跡は, $x / d \fallingdotseq 0.3$ で半径方向に最も大きく広がり, その後, 高 温空気噴流の流れに従って飛行する.

微粉粒子の飛行軌跡の数值解析結果, および可視 化・観察結果から，円形ノズル形の場合，大部分の粒 子が噴流の外側領域 $\left(T<120^{\circ} \mathrm{C}\right)$ を飛行するのに対し, 三重管ノズル形では，ほとんどすべての粒子が $T>$ $200^{\circ} \mathrm{C}$ の領域を通過する。

以上の結果より, 新たに提案した三重管ノズル形で 


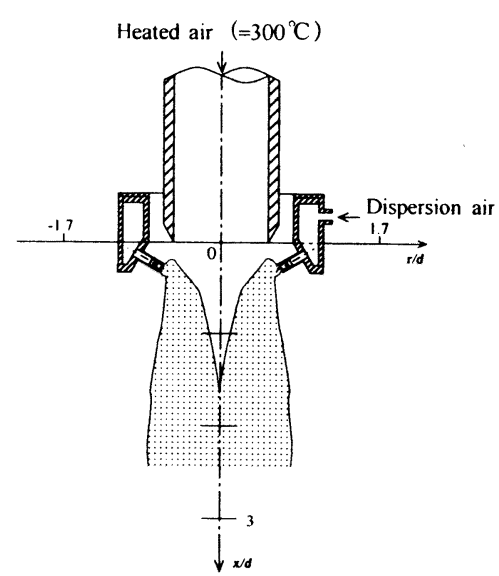

Fig. 12 Particle trajectories of the pipe nozzle

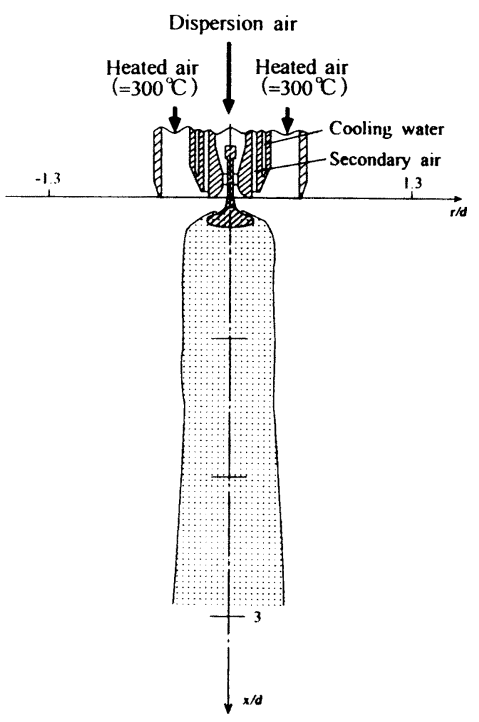

Fig. 13 Particle trajectories of the three nozzle

は, すべての粒子を $T>200^{\circ} \mathrm{C}$ 高温の温度場を飛行 させることができることがわかった。

6・4 球形化特性 図 14 に表面改質性能を, 平均 円形度とカップリングで示す.

円形ノズル形では, 粒子の供給速度を増加させると, 平均円形度は減少しカップリングは増加する。この 際, 平均円形度の減少は, 高温空気噴流中での粒子の 個数が増加するため, 粒子 1 個に与えられる伝熱量が 減少したことによると考えられる。また，カップリン グの増加は, 高温空気噴流中での粒子の個数が増加す るため粒子同士の衝突が増加したことによると考えら れる。

三重管ノズル形では, 高温空気噴流の温度が増加す

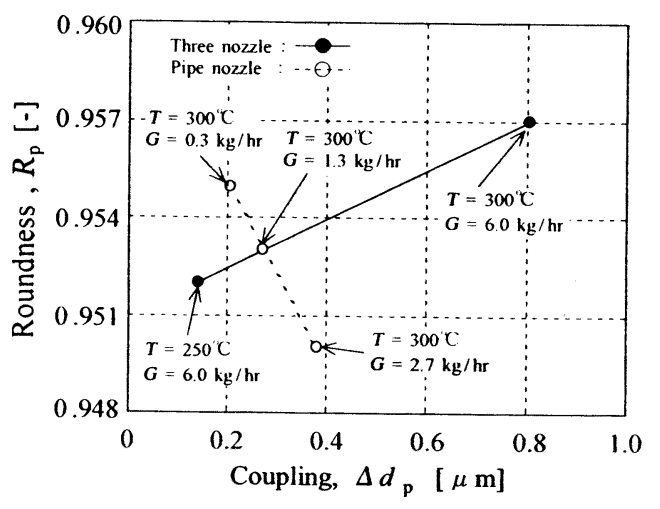

Fig. 14 Roundness and coupling

ると, 平均円形度とカップリングはともに増加する。 この際, 平均円形度の増加は, 高温空気噴流から粒子 に与えられる伝熱量が増加することによると考えられ る.また，カップリングの増加は，高温領域が流れ方 向に長いため粒子同士の衝突が増加することによると 考えられる。

円形，および三重管ノズル形の球形化性能は，図 14 中の実線と破線の交点より求めることができる、すな わち, 三重管ノズル形で交点の平均円形度 $R_{p}=0.953$ とカップリング $\Delta d_{p}=0.27 \mu \mathrm{m}$ を得ることができるの は, 供給速度が $G=6.0 \mathrm{~kg} / \mathrm{h}$, 高温空気噴流の温度が $T \fallingdotseq 260^{\circ} \mathrm{C}$ 場合である。この場合の円形および三重 管ノズル形のエネルギー効率 $\eta_{r}, \eta_{m u}$ 供給速度 $(G$ : $\mathrm{kg} / \mathrm{h}) /$ 高温空気噴流の熱量 $\left(Q_{3}=m c_{p} T: \mathrm{kJ} / \mathrm{h}\right)$ $[\mathrm{kg} / \mathrm{kJ}]\}$ を求め, それらの比, すなわちエネルギー 効率比 $\sigma\left(=\eta_{m u} / \eta_{r}\right)$ を算出すると, 約 5.3 を得る.

すなわち, 三重管ノズル形球形化装置のエネルギー 効率は, 円形ノズル形の約 5.3 倍になり, 大きく改 善・向上される.

\section{7. 結 論}

円形，および新たに提案した三重管ノズルからの噴 流の伝熱特性，およびそれらの高温空気噴流を使った 微粉粒子の表面改質, 球形化特性について検討した。

得られたおもな結果は，以下のようである。

（1）新たに提案した三重管ノズル形球形化装置 は, 円形ノズル形に比べ，微粉粒子をより高温領域に 流入させることができる.

(2) 球形化特性 (平均円形度 $R_{p}$ ) は, 微粉粒子へ の伝熱量 $Q_{2}[\mathrm{~J}]$ の増加とともに大きくなり以下の関 係で示すことができる.

$$
R_{p}=\left(-4.84 \times 10^{9}\right) Q_{2}^{2}+36000 Q_{2}+0.91
$$

ここで, $Q_{2}[\mathrm{~J}]$ 
（3）三重管ノズル形球形化装置のエネルギー効率 は, 円形ノズル形の約 5.3 倍になり, 大きく改善・向 上される.

\section{文献}

（1）日本化学工学会, 化学工学ハンドブック, (1988), 836837, 丸善.

（2）日本粉体工学会, 粉砕・分級・表面改質，(2001)，538 539, NGT.

（3）清水淳, 電子写真用トナーの特性制御と高機能化, 日本
粉体工学会誌, No. 38(2001), 506-507.

（4）中村裕計・社河内敏彦・楠田敦，微粉粒子の表面改質 球形化における高温空気噴流の流動と伝熱特性, 日本化 学工学論文集, No. 6(2003), 836-841.

（5）狩野武, 粉体粒子の挙動，(1977)，278-281, 産業技術七 ンター

(6) Crow, C. T., Sharma, M. P. and Stock, D. E., The Particle-Source-In-Cell Model for Gas-Droplet Flows, Trans. ASME, J. Fluids Eng., 99-2 (1977), 325-332.

（7）社河内敏彦・中村裕計・森本洋史・奥本昌宏, 高温空気 噴流の流動伝熱特性とその応用, 日本機械学会講演論文 集, No. 03-30 (2003), 283-284. 